(C) 2020 by the Arizona Board of Regents on behalf of the University of Arizona. This is an Open Access article, distributed under the terms of the Creative Commons Attribution licence (http://creativecommons. org/licenses/by/4.0/), which permits unrestricted re-use, distribution, and reproduction in any medium, provided the original work is properly cited.

\title{
A RADIOCARBON DATING APPROACH TO THE DEPOSITION AND REMOVAL OF HUMAN BONE REMAINS IN MEGALITHIC MONUMENTS
}

\author{
Gonzalo Aranda Jiménez ${ }^{*}$ (1) Marta Díaz-Zorita Bonilla ${ }^{2,3}$ (D) Derek Hamilton ${ }^{4}$ (D) • \\ Lara Milesi ${ }^{1}$ (I) Margarita Sánchez Romero ${ }^{1}$ (i)

\footnotetext{
${ }^{1}$ Department of Prehistory and Archaeology, University of Granada, Campus Cartuja s/n, 18071, Granada, Spain

${ }^{2}$ Institut für Ur- und Frühgeschichte und Archäologie des Mittelalters, University of Tübingen, Hölderlinstr. 12, 72074, Tübingen, Germany

${ }^{3}$ SFB 1070 "Ressourcenkulturen", Gartenstr. 29, 72074, Tübingen, University of Tübingen

${ }^{4}$ Scottish Universities Environmental Research Centre, Rankine Avenue, East Kilbride, G75 0QF, UK
}

\begin{abstract}
The formation of commingled human bone assemblages is a key aspect for better understanding funerary rituals. The megalithic cemetery of Panoría (Spain) provides an excellent opportunity to explore bone assemblage formation thanks to the recent excavation of an undisturbed burial. For this purpose, we have approached the differential skeletal representation found between bone and teeth at the site through radiocarbon $\left({ }^{14} \mathrm{C}\right)$ dating and Bayesian modeling. The comparison between the series of ${ }^{14} \mathrm{C}$ dates on bone $(n=12)$ and teeth $(n=14)$ stress three main aspects: (1) the dates of teeth show a long period of funerary use before the deposition of the human bone remains; (2) both kinds of samples appear to be chronologically sequenced; the end of the teeth ${ }^{14} \mathrm{C}$ series matches with the beginning of human bone deposition; and (3) bone remains span a short period, not more than a few decades, which probably represents the last episode of intense mortuary activity. These differences suggest that teeth could be the evidence of skeletal depositions subsequently removed from the tomb. The deposition and removal of bone remains emerge as key aspects in the formation of the bone assemblage.
\end{abstract}

KEYWORDS: Bayesian modeling, collective tombs, funerary ritual, funerary taphonomy, Iberian Peninsula, megalithic phenomenon, radiocarbon dating.

\section{INTRODUCTION}

Ritual and funerary practices in megalithic monuments normally appear as complex palimpsests. The frequent use of these funerary spaces, in many cases over long periods of time, has created mortuary deposits characterized by masses of stratified, fragmented and mixed human bones and grave goods that appear piled on top of each other, overlapping in many occasions. The underlying assumption has traditionally been that this kind of bone assemblage was formed mainly as a result of primary depositions disturbed by later activities, mainly subsequent burials (Scarre 2007; Whittle et al. 2011; Díaz-Zorita Bonilla 2017; Aranda Jiménez et al. 2020).

Nevertheless, bone assemblages found in megalithic tombs could be the result of many factors that may interact in very complex ways (Knüsel and Robb 2016; Robb 2016). The deposition of human remains is the first step in assemblage formation. Skeletal remains can be deposited as articulated bodies (primary deposition) or as disarticulated bones which have already been previously buried or defleshed elsewhere (secondary deposition). Once the human remains are deposited inside megalithic tombs, they could be removed intentionally or by forces such as scavenging animals. Additionally, bone remains could also be destroyed in situ as a result of chemical dissolution by local ground conditions, damage caused by plant roots, bone fragmentation during subsequent depositional events, and/or mechanical compression from sediment pressure, among others.

\footnotetext{
*Corresponding author. Email: garanda@ugr.es.
} 
In megalithic tombs these factors interact across multi-depositional events that usually occur during long periods spanning centuries of mortuary activity. Therefore, megalithic palimpsests are created through overlapping depositional events over variable periods of time with the variable erasing of previous material traces (Lucas 2005; Bailey 2007). The study of bone assemblage formation in megalithic tombs is a challenging task that has found additional constraints to be properly explored. For instance, undisturbed megalithic burials are extremely unusual. Due to the high visibility of these monuments within the landscape, looting activities are common which mean that most of the bone remains have been disturbed and lost in antiquity. Furthermore, dolmens have traditionally been the focus of old excavations that did not use systematic recording techniques of skeletal remains. As a general rule, many of these excavations were primarily concentrated in recovering the skulls and long bones (Schulting et al. 2010; Robb 2016).

The megalithic phenomenon in southeastern Iberia fits this scenario well. Most of the megalithic cemeteries of southeastern Iberia were excavated between the end of the 19th and the beginning of the 20th centuries (Siret 1891 [2001], 1893, 1906-07; Leisner and Leisner 1943). At those times, the excavation policy was mainly focused on the grave goods and not in the human remains, which were unevenly recorded. Moreover, the history of bone collections has also added further obstacles for modern research using these archives, and include such issues as mislabelling, the mixing of bones from different tombs, inadequate storage conditions, the splitting-up of specific remains for specialist study or exhibitions that never were reunified and so on (Maicas Ramos 2005, 2007; Lorrio Alvarado 2008, 2011; Peña Romo 2011). According to these constraints, bone assemblage formation and the ritual practices associated with them have only been approached from very general points of view.

The recent excavation of the megalithic cemetery of Panoría offers an excellent opportunity to avoid several of these restrictions because an undisturbed megalithic burial was found (Benavides López et al. 2016; Díaz-Zorita Bonilla et al. 2017; Aranda Jiménez et al. 2018a, 2018b). The anthropological deposit of Tomb 10 showed a remarkable state of preservation without major post-ritual disturbances. Thanks to the careful recording techniques used during fieldwork including trained bioarchaeologist excavators and the systematic sieving of sediments, we are highly confident that $100 \%$ of the human bones forming the palimpsest were recovered. The formation of the bone assemblage in this tomb will be discussed in this paper and it will focus mainly on two different social actions-the deposition and the removal of skeletal remains. For this purpose, we explore a novel methodological strategy based on radiocarbon $\left({ }^{14} \mathrm{C}\right)$ dating. In the following pages, the general background of the cemetery and especially of Tomb 10 will be considered; then the result of the new ${ }^{14} \mathrm{C}$ series will be analyzed in a Bayesian framework and finally, the ritual and social implications of the palimpsest's formation will be discussed.

\section{ARCHAEOLOGICAL BACKGROUND: THE TOMB 10 AT PANORÍA CEMETERY}

The megalithic cemetery of Panoría is located in the southeast of the Iberian Peninsula (Figure 1). Discovered in 2012, it is the latest addition to the known megalithic cemeteries spread across the Guadix Basin. This region stands out as one of the most important megalithic concentrations in Western Europe with more than 400 megalithic tombs (Leisner and Leisner 1943). The Panoría necropolis occupies a strategic position overlooking most of the Guadix Basin. Intensive surveys have found 19 dolmens that consist of tombs with 


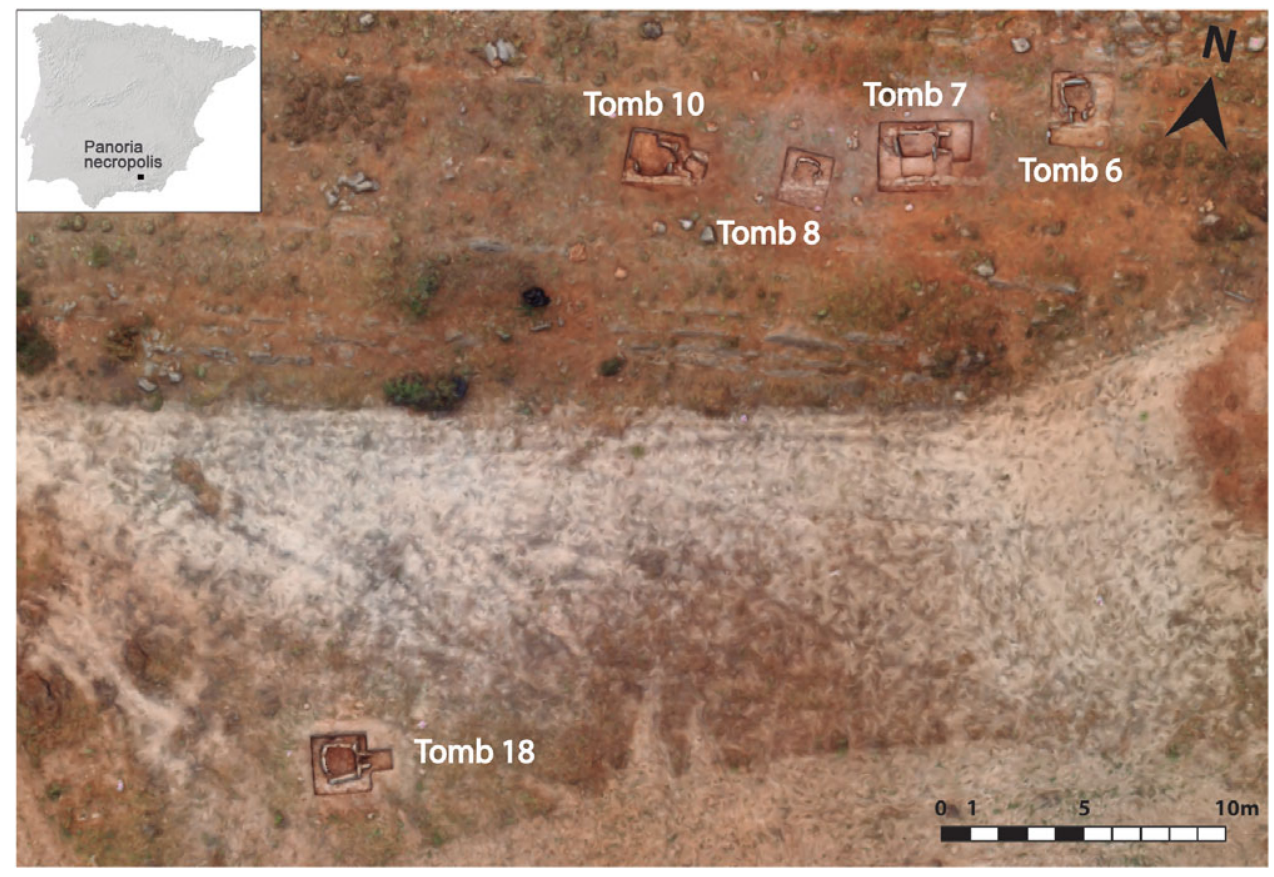

Figure 1 Orthophotography with the location of the 5 excavated tombs at Panoría cemetery.

rectangular and trapezoidal chambers-normally between 1.10 and $1.60 \mathrm{~m}$ in length-and short passages. Five of these megalithic tombs were excavated between February and June 2015. According with the ${ }^{14} \mathrm{C}$ chronology, the cemetery was in use during a long period that began in the Late Neolithic (3525-3195 cal BC), reaching the most intensive ritual activity during the Copper Age and ending in the Early Bronze Age (2125-1980 cal BC) (Aranda Jiménez et al. 2018a).

Of the five excavated tombs, four were at least partially affected by disturbance activities. Only at Tomb 10 were no explicit traces of later human interference detected. In this case, the mortuary remains were found in the chamber and passage (Figure 2). Different occupation phases were not distinguishable as human bones were found in one compact burial layer of fragmented and mixed skeletal remains that were discovered piled on top of each other. Although most of the bones were scattered, in several cases complete individuals or specific anatomical parts appeared in an articulated or semi-articulated position, which means the tomb was a place for primary depositions later disturbed by different factors. Despite the scattered and fragmented nature of the bone remains, primary depositions reach $10.5 \%$ of the entire bone assemblage (Díaz-Zorita Bonilla et al. 2017; Aranda Jiménez et al. 2018a, 2018b).

The whole collection totals 11,551 human bones and 368 teeth. The skeletal remains belong to male, female, and subadult individuals of all ages, although most of them fall into the adult range. All the anatomical parts are represented in the skeletal assemblage (Figure 3). The osteological profile of Tomb 10 shows a good representation of small and fragile bones such as hands, feet, teeth, vertebrae and ribs in the same level of magnitude as that of 


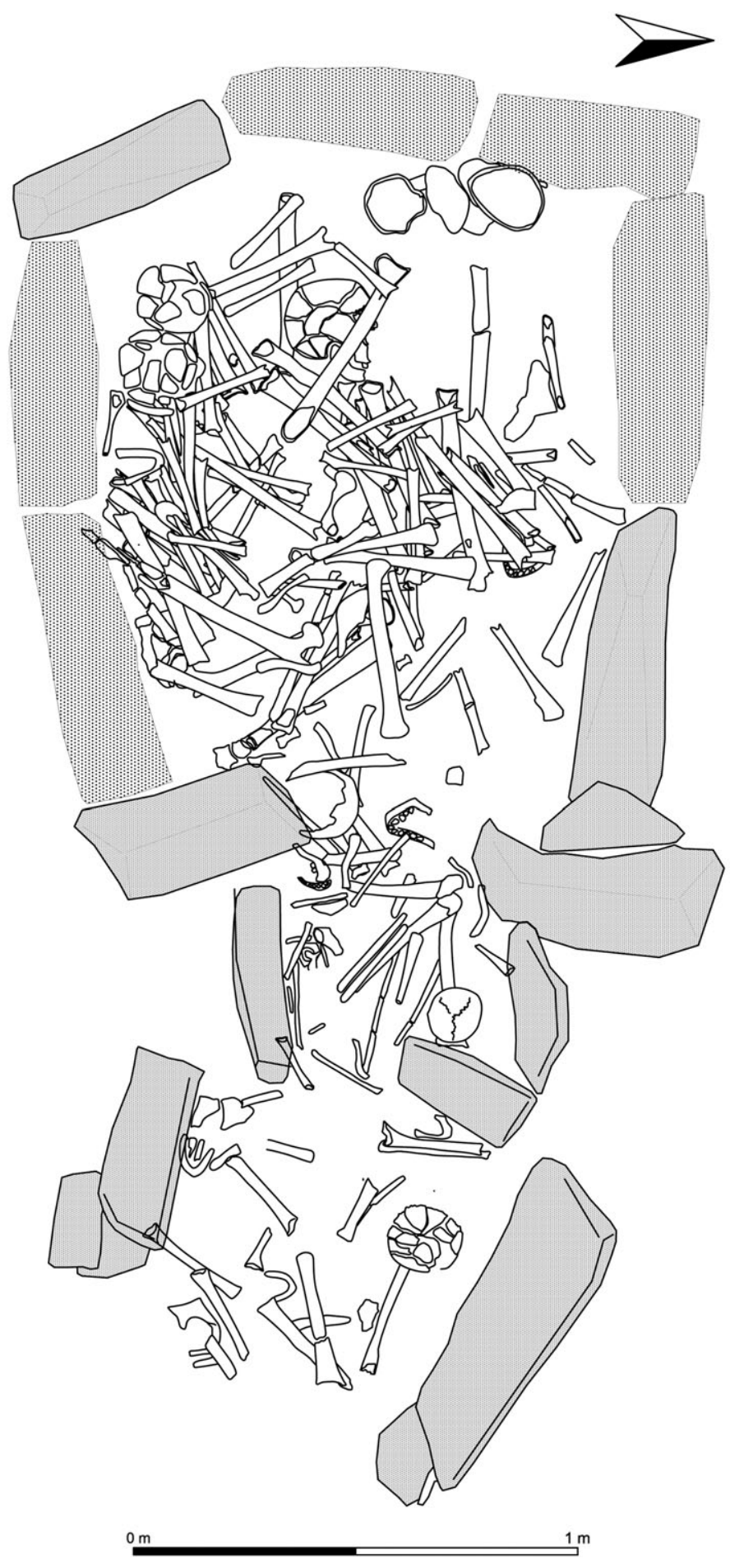

Figure 2 Anthropological remains from Tomb 10 of the Panoría cemetery. 


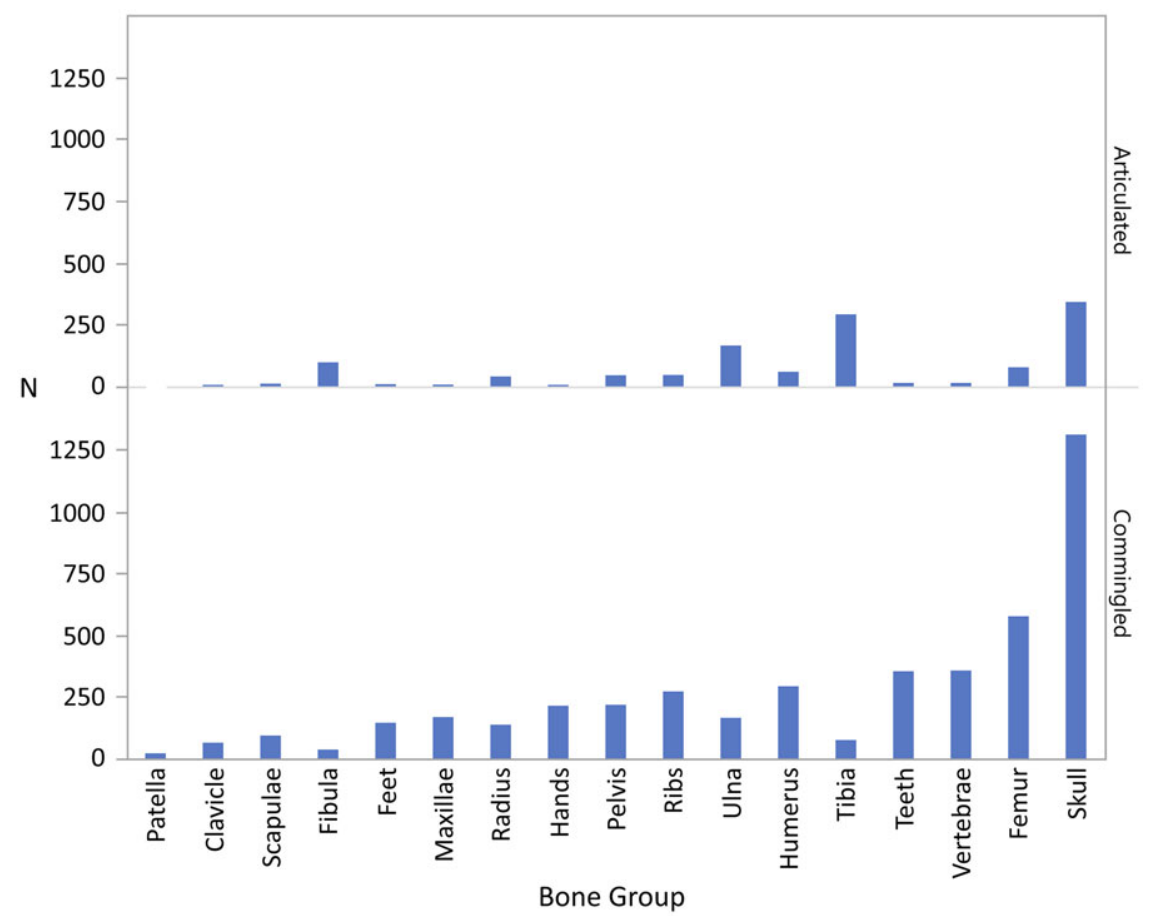

Figure 3 The osteological profile of Tomb 10 at the Panoría cemetery.

major bones such as humerus, radius, ulna and tibia ${ }^{1}$. The representation of small and fragile bones is consistent with funerary rituals based on primary depositions affected by selective removal of cranial and long bones. This osteological profile would reflect a partly residual assemblage, just the opposite as would be expected in mortuary rituals based on sequential primary inhumations and secondary burials characterized by the lack or the very low representation of fragile and small bones resulting from a differential preservation caused by in situ destruction and later mortuary depositions (Chambon 2003; Munoz et al. 2012; Robb 2016).

For exploring the chronology and temporality of this mortuary deposit we focused on bone samples in order to include the articulated individuals for the ${ }^{14} \mathrm{C}$ dating. Articulated bone samples are especially suitable for dating, as they are reflective of being in their primary contexts, such that contemporaneity between the date obtained and the act of deposition can be guaranteed. Following the sampling strategy, successfully tested in our previous research (Aranda Jiménez and Lozano Medina 2014; Aranda Jiménez et al. 2017, 2018c, 2020; Lozano Medina and Aranda Jiménez 2018), we also selected the MNI to be ${ }^{14} \mathrm{C}$ dated because in commingled bone assemblages this is probably the best way of ensuring that no individual is dated twice. As a result, the MNI was 12, a figure calculated on the basis of 11 left femurs from adults and a fibula from a juvenile. Of the 12 samples three belong to skeletons still in anatomical connection and the remaining nine femurs were found in a disarticulated and scattered state (Table 1). The 12 samples were successfully

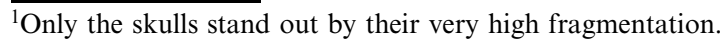


Table $1{ }^{14} \mathrm{C}$ series of the Tomb 10 at Panoría cemetery including the quality markers of the bone collagen and $\delta^{13} \mathrm{C}$ and $\delta^{15} \mathrm{~N}$ isotope values. Tooth 63 belongs to the upper left canine and tooth 45 to the lower right premolar 2.




Table 1 (Continued)

\begin{tabular}{|c|c|c|c|c|c|c|c|c|c|c|}
\hline $\begin{array}{l}\text { Laboratory } \\
\text { code }\end{array}$ & $\begin{array}{c}\text { Type of material and } \\
\text { age }\end{array}$ & $\begin{array}{c}{ }^{14} \mathrm{C} \text { age } \\
\text { (BP) }\end{array}$ & $\begin{array}{c}\delta^{13} \mathrm{C} \\
\text { IRMS } \\
(\% 0)\end{array}$ & $\begin{array}{l}\delta^{15} \mathrm{~N} \\
(\% 0)\end{array}$ & $\mathrm{C}: \mathrm{N}$ & $\% \mathrm{C}$ & $\% \mathrm{~N}$ & $\begin{array}{l}\% \text { yield } \\
\text { collagen }\end{array}$ & $\begin{array}{l}\text { Calibrated date } \\
\text { (68\% confidence) } \\
\text { cal BC }\end{array}$ & $\begin{array}{c}\text { Calibrated date } \\
\text { (95\% confidence) } \\
\text { cal BC }\end{array}$ \\
\hline $\begin{array}{l}\text { SUERC-86898 } \\
\text {. } 86\end{array}$ & Tooth 45 (adult) & $4072 \pm 34$ & -19.5 & 8.7 & 3.4 & 43.5 & 15 & 7.3 & $2830-2500$ & $2860-2490$ \\
\hline SUERC-86892 & Tooth 45 (adult) & $4026 \pm 34$ & -19.2 & 10 & 3.4 & 42.8 & 14.7 & 8.3 & $2580-2490$ & $2830-2470$ \\
\hline SUERC-86893 & Tooth 45 (adult) & $4025 \pm 32$ & -19.6 & 9.0 & 3.3 & 43 & 15.1 & 7.4 & $2580-2490$ & $2620-2470$ \\
\hline SUERC-86891 & Tooth 45 (adult) & $4019 \pm 34$ & -19.1 & 8.5 & 3.4 & 44.3 & 15 & 6.8 & $2570-2490$ & $2620-2470$ \\
\hline SUERC-86890 & Tooth 45 (adult) & $3954 \pm 34$ & -19.4 & 9.8 & 3.4 & 44.5 & 15.2 & 7.2 & $2570-2350$ & $2570-2340$ \\
\hline
\end{tabular}


dated, providing us a large ${ }^{14} \mathrm{C}$ series that certainly captures the temporality of the multidepositional skeletal remains found in the tomb (Aranda Jiménez et al. 2018a).

According to the preferred Bayesian model of this ${ }^{14} \mathrm{C}$ series discussed in depth elsewhere (Aranda Jiménez et al. 2018a), we stated that in Tomb 10 two phases of mortuary activity can be identified according with the stratigraphic relationship between the samples. The early and main phase of ritual activity shows that the tomb was in use over a few decades at the beginning of the second half of the third millennium cal $\mathrm{BC}$, for a period of between 1 and 40 years (68\% probability). After a hiatus (210-380 years at $68 \%$ probability), the tomb was reused again during a very short period at the beginning of the Early Bronze Age. For the first time in southeastern Iberia, it was demonstrated that megalithic tombs were used at different temporal scales and intensities, ranging from a few decades to centuries. We concluded that Tomb 10 challenges the traditional assumption that the megalithic monuments remained in use over a span of centuries and contain long sequences of mortuary depositions (Aranda Jiménez et al. 2018a).

Apparently, these conclusions seem to be robust because of the combination of several factors such as the undisturbed nature of the burial, the systematic recording methods used during the excavation, the fine-grained bioarchaeological analysis of the human remains and the large ${ }^{14} \mathrm{C}$ series obtained. Nevertheless, we have moved on to explore if this ${ }^{14} \mathrm{C}$ series really captures the complexity of the bone assemblage formation and the use-life of the tomb. In other words, were the depositional events of human remains concentrated in a short period of time? Can the in situ decomposition of bones explain the different rates of bone preservation? Could the removal of skeletal remains also influence the palimpsest's formation and the period of use determined through the use of ${ }^{14} \mathrm{C}$ dates? And, if this was the case, how can we approach these social actions?

To address these new research questions, we focussed our attention on the differences found between the MNI estimated in teeth and bones. Based on teeth, there was more than double the number of individuals buried in Tomb 10 (28 versus 12). Could these discrepancies be associated not only with the in situ bone decomposition but also with the removal of skeletal remains as the anatomical part representation suggests? Teeth have three main properties: small size, good preservation in different taphonomic conditions due to high mineral content and the fact they easily detach from mandibles and maxillae after the skeletal decomposition begins (Buikstra and Ubelaker 1994; Hillson 1996). Could these teeth represent lost evidence of human bone deposition episodes that were later subtracted from the tomb? Could the removal of skeletal remains explain, at least partially, the differences found in the human bone preservation? To answer these questions, we developed comparative ${ }^{14} \mathrm{C}$ chronologies as an excellent pathway to explore how the bone assemblage was formed.

\section{MATERIALS AND METHODS}

Bearing in mind the above discussion, we decided to ${ }^{14} \mathrm{C}$ date the teeth in order to explore if teeth and bone samples could belong to people that died at the same or different time. Two main alternative possibilities were expected: (1) the ${ }^{14} \mathrm{C}$ dating would show previous depositions of human remains that went unnoticed when analyzing the ${ }^{14} \mathrm{C}$ series from bone samples; or (2) ${ }^{14} \mathrm{C}$ measurements would match with the existing dataset. The MNI from the teeth was 28 , a figure based on the permanent tooth 45 for adults and on the 
deciduous tooth 63 for subadult individuals. Of the 28 potential samples we focused on loose teeth, meaning those teeth that remained in situ within a mandible or the maxillae were excluded. Also those teeth whose degree of preservation gave them low probabilities for successful ${ }^{14} \mathrm{C}$ dating were also not considered. As a result, there were 15 possible samples for ${ }^{14} \mathrm{C}$ dating. All of them were found mixed with bone remains in the same archaeological deposit. For cost efficiency reasons, in a first attempt only 5 samples were measured. After the evaluation, we expanded the dating to the other 10 samples, which meant that all 15 samples were submitted for dating (Table 1). While all 15 samples produced ${ }^{14} \mathrm{C}$ results, GU-51331 had a low collagen yield that was just above the $1 \%$ minimum threshold with the total amount of collagen produced only suitable for a single small target. The measured result was approximately 1000 years earlier than the main series of dates. Since the sample was marginal in size, without enough material to separately check the $\% \mathrm{C}, \% \mathrm{~N}$, and $\mathrm{C}: \mathrm{N}$ through CF-IRMS, the result was subsequently withdrawn by the lab.

All samples were measured using accelerator mass spectrometry (AMS) in the Scottish Universities Environmental Research Centre (SUERC) ${ }^{2} .{ }^{14} \mathrm{C}$ dates were calibrated using the internationally agreed atmospheric curve, IntCal13 (Reimer et al. 2013), and the OxCal v4.3 computer program (Bronk Ramsey 2001, 2009a). Calibrated ranges were obtained using the probability method (Stuiver and Reimer 1993) and the endpoints were rounded out by 10 years when the error was greater than or equal to 25 years and by 5 years when the error was less than 25 years (Stuiver and Polach 1977; Millard 2014). The quality of the bone collagen can be checked in Table 1. The new chronological series was modeled in a Bayesian framework using the OxCal program v4.3 (Bronk Ramsey 2001, 2009a).

When ${ }^{14} \mathrm{C}$ dating anthropological remains it is very important to ensure that the carbon in the sampled bones was in equilibrium with the atmosphere, otherwise our interpretations will not be on solid foundations. Bone collagen from omnivores such as humans may derive from a diet based on marine and freshwater resources, which means that ${ }^{14} \mathrm{C}$ measurements could be strongly influenced by the reservoir effect (Stuiver and Braziunas 1993; Lanting and van der Plicht 1998; Cook et al. 2001). In these cases, the carbon is not in equilibrium with the atmosphere, presenting an earlier date than any contemporaneous terrestrial organism. Although the distance of the Panoría necropolis from the sea (over $130 \mathrm{~km}$ ) presumably precludes the consumption of significant amounts of marine resources, the appearance of seashells as grave goods suggests that seafood consumption cannot be ruled out. The consumption of appreciable quantities of freshwater fish and waterfowl also seems very unlikely, taking into account the absence of wetlands in the region and that most of the watercourses are highly seasonal. Nevertheless, to explore the potential dietary reservoir effect all the samples selected to be dated also separately underwent $\delta^{13} \mathrm{C}$ and $\delta^{15} \mathrm{~N}$ stable isotope analysis.

\section{RESULTS AND DISCUSSION}

The $\delta^{13} \mathrm{C}$ values for teeth of adult individuals range from -19.1 to $-19.8 \%$ and the mean is $-19.5 \% \pm 0.26(1 \sigma)$. The $\delta^{15} \mathrm{~N}$ ratios range from +7.8 to $+10.3 \%$ and the mean is $+8.9 \%$ o $\pm 0.8(1 \sigma)^{3}$. These values match perfectly with the ratios of the bone samples,

\footnotetext{
${ }^{2}$ The methods used by the SUERC are described by Dunbar et al. (2016).

${ }^{3}$ The individual classified as Infant I ( 2 years \pm 8 months old) has not been included in these estimates because their isotopic values could be associated with the breastfeeding signal rather than to the consumption of marine resources.
} 
$\delta^{13} \mathrm{C}-19.6 \%{ }^{\circ} \pm 0.25(1 \sigma)$ and $\delta^{15} \mathrm{~N}+8.9 \% \pm 0.65(1 \sigma)$, that have been discussed in-depth elsewhere (Díaz-Zorita Bonilla et al. 2019). According to these isotopic results, the diet was based on $\mathrm{C}_{3}$ plants and terrestrial animals ${ }^{4}$, with no evidence of any relevant intake of marine or freshwater resources. Therefore, the ${ }^{14} \mathrm{C}$ dates can be considered accurate estimations in equilibrium with the atmosphere. The carbon and nitrogen isotopic values of Panoría are consistent with the available paleodiet studies of southeastern megalithic societies carried out in cemeteries such as Los Millares (Waterman et al. 2017) and El Barranquete (Díaz-Zorita Bonilla et al. 2019).

The ${ }^{14} \mathrm{C}$ series of Tomb 10 at Panoría consists of 26 dates, 12 from bones and 14 from teeth samples. Of the 26 dates three belong to individuals still in anatomical connection, which means that 23 dates come from scattered, fragmented and disarticulated teeth and bones mixed in the same burial deposit. In a first Bayesian model we have considered the possibility for there to be statistical outliers. We built a model that included all the results from teeth and the earlier group of dates on bones, excluding the most recent (ETH-69965 and Beta-448207). These were modeled as a single phase of activity, and using the General outlier model (Bronk Ramsey 2009b), each result was given a 5\% prior probability of being an outlier. This model suggests SUERC-84314 and SUERC-86899 are both outliers $(100 \%$ and $83 \%$ posterior probability). After removing these two outliers from the dataset, a model was rerun that included the remaining bone and teeth dates from the primary phase of use of the tomb. This model has good agreement $\left(\mathrm{A}_{\text {model }}=138\right)$ (Figure 4). It estimates this phase of burial began in either 2655-2575 cal BC (54\% probability; Figure 4; start: Panoría main) or 2560-2505 cal BC (41\% probability), and probably in either $2630-2590$ cal BC (37\% probability) or 2530-2505 cal BC (31\% probability). This phase of activity ended in 2465-2375 cal BC (95\% probability; Figure 4; end: Panoría main), and probably in $2465-2425$ cal BC (68\% probability). When considering the earliest dated remains as outliers in the larger dataset-either relating to the earliest activity, reworked teeth, or purely as statistical outliers - the model for Tomb 10 still indicates a potentially long period of use in the main period of burial activity, perhaps around two centuries.

In a second Bayesian model all the ${ }^{14} \mathrm{C}$ dates were modeled according to the type of dated sample for comparative purposes (Figure 5). All the teeth were clustered in one phase of continuous activity and the bone dates were arranged in two phases of mortuary activity according with their location and stratigraphic position (see Aranda Jiménez et al. 2018a for the prior information discussion). Both phases-teeth and bones-present a good index of agreement $\left(\mathrm{A}_{\text {model }}=157 \%\right)^{5}$, which indicates that the ${ }^{14} \mathrm{C}$ dates conform to the archaeological information incorporated in the Bayesian analysis. According to this model (Figure 5), three main aspects can be highlighted:

1. The beginning of mortuary activity sharply contrasts between the ${ }^{14} \mathrm{C}$ dates from the teeth and bone. In the first case, the earliest human remains were placed in the tomb in 3360-3100 cal BC (95\% probability; Figure 5; start: teeth), probably in 3230-3125 cal

\footnotetext{
${ }^{4}$ The lack of faunal remains in the excavated tombs at Panoría makes it impossible to determine the terrestrial and marine endpoints. Therefore, in accordance with the $\delta^{15} \mathrm{~N}$ values and by following the increase of about $3-5 \%$ in the consumer over their diet (DeNiro and Epstein 1981; Schoeninger and DeNiro 1984; Bocherens and Drucker 2003), we can estimate the herbivore ecosystem.

${ }^{5}$ The Bayesian modeling incorporates a statistic known as the index of agreement, which calculates the reliability of the model and provides useful information for identifying samples whose archaeological taphonomy has not been properly characterized. This index estimates a figure of how well any posterior probability distribution agrees with the relative sequential information. If the index of agreement falls below $60 \%$, the ${ }^{14} \mathrm{C}$ measurement should be considered somewhat problematic (Bronk Ramsey 1995: 427-428).
} 
OxCal v4.3.2 Bronk Ramsey (2017); r:5 IntCal13 atmospheric curve (Reimer et al 2013)

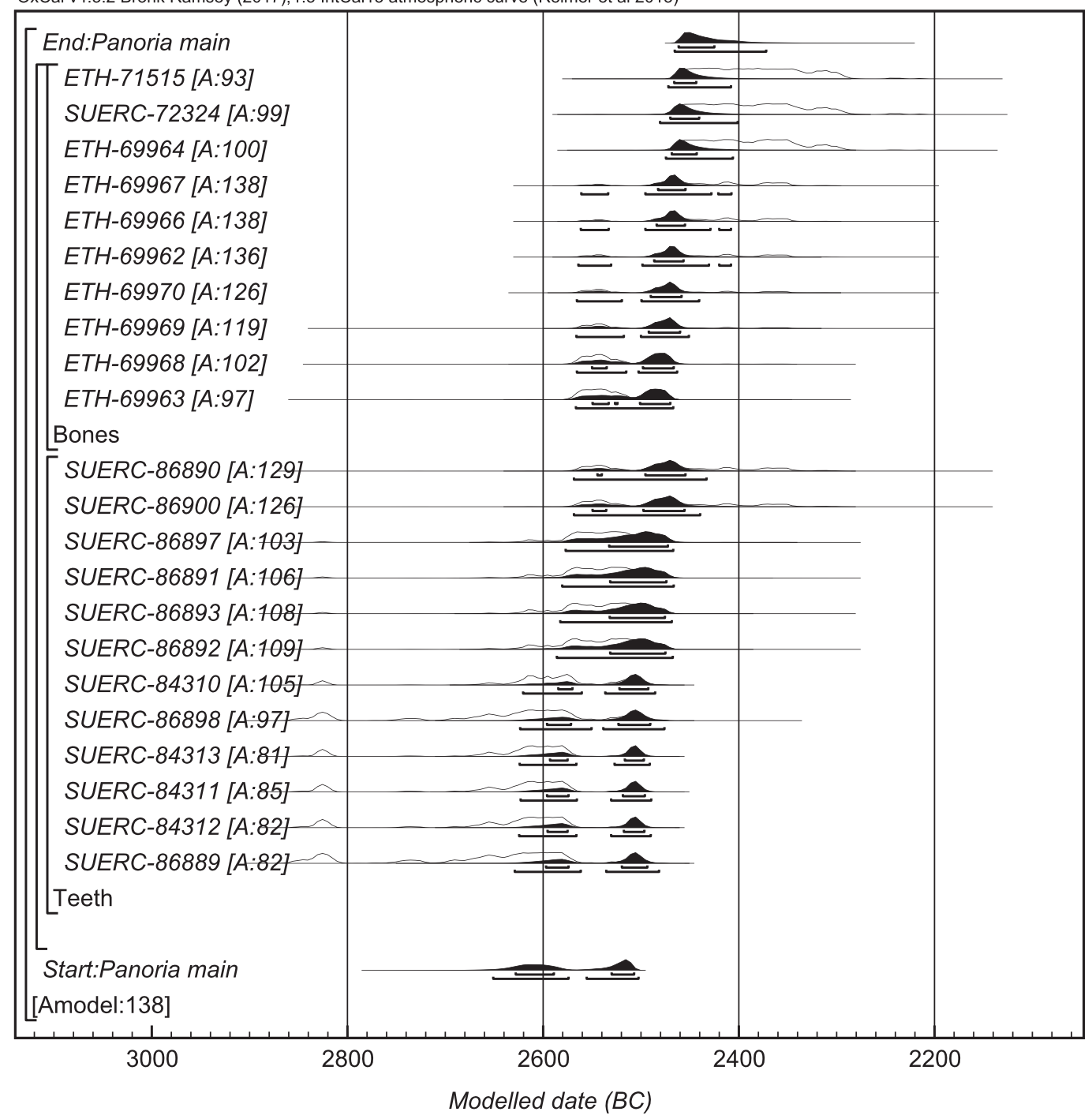

Figure 4 Probability distribution of dates from the Tomb 10 at the Panoría cemetery. Each date shows two distributions: light grey represents the ${ }^{14} \mathrm{C}$ calibration and dark grey indicates the result of the Bayesian model (posterior density estimates). Distributions other than those relating to particular dates correspond to aspects of the model. The square brackets down the left-hand side and the OxCal keywords define the overall model exactly.

$B C(68 \%$ probability). In the second case, mortuary activity began in $2515-2465$ cal $B C$ (95\% probability; Figure 5; start: bone), and probably between 2490-2470 cal BC (68\% probability). In calendar years, these differences would imply that the new ${ }^{14} \mathrm{C}$ series on teeth moves the start of funerary depositions earlier by about three-quarters of a millennium (between 605 and 895 years; 95\% probability; Figure 5; calculated Difference between start: teeth and start: bone 1). 
OxCal v4.3.2 Bronk Ramsey (2017); r:1 IntCal13 atmospheric curve (Reimer et al 2013)

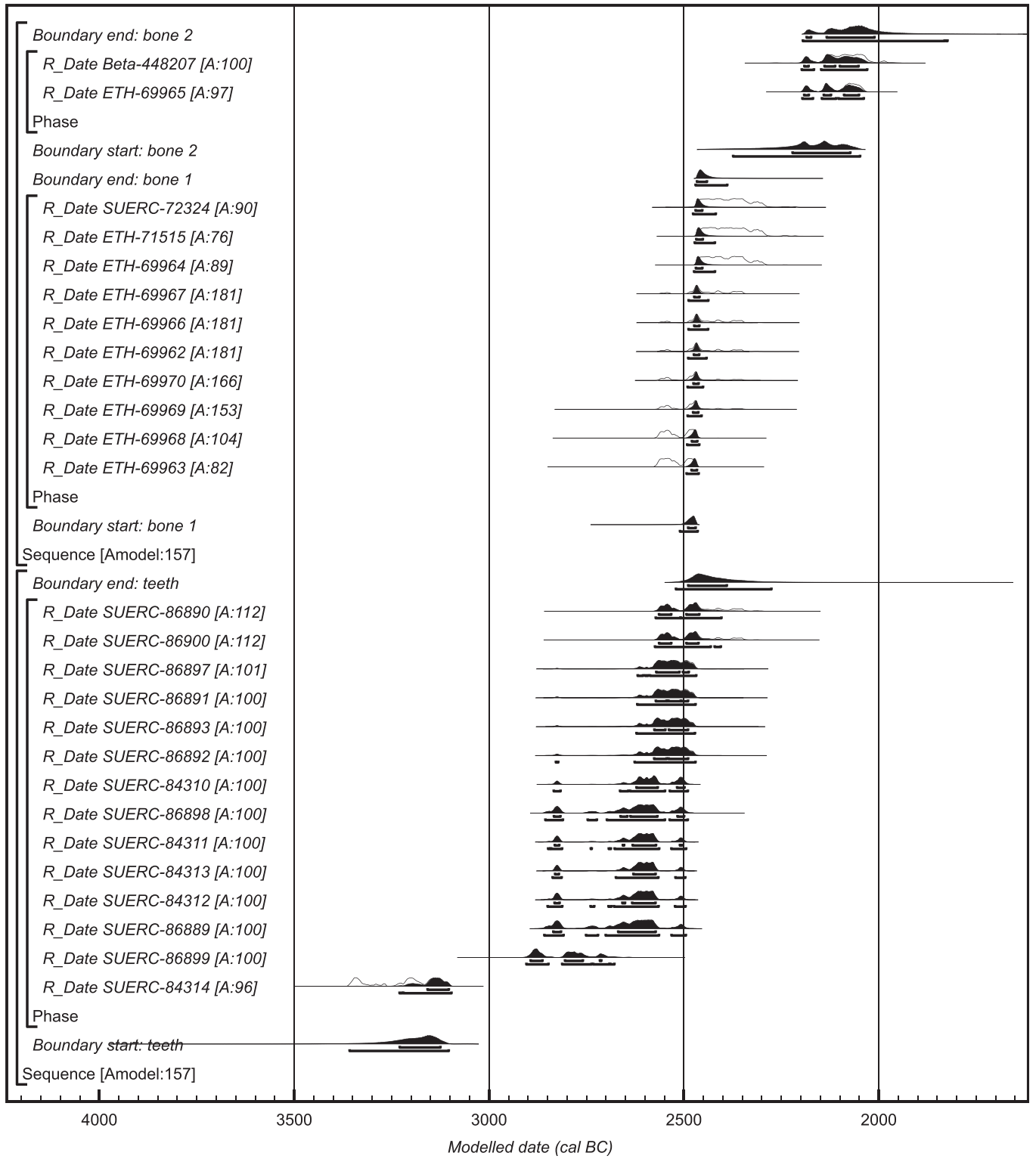

Figure 5 Probability distribution of dates from the Tomb 10 at the Panoría cemetery (second model). The format is identical to that in Figure 3.

2. Although the earliest funerary deposition occurred in the third quarter of the fourth millennium (SUERC-84314; Figure 5; 3230-3095 cal BC; 95\% probability), most of the interments based on teeth were concentrated in the first half of the third millennium cal BC. The end of this series $(2525-2270 \mathrm{cal} \mathrm{BC} ; 95 \%$ probability; Figure 5; end: teeth) is indistinguishable from either the beginning or end of the primary phase of human bone deposition (2515-2465 cal BC; 95\% probability; Figure 5; start: bone 1) (2470-2385 cal $B C ; 95 \%$ probability; Figure 5; end: bone 1). The coexistence between the teeth and bone 
${ }^{14} \mathrm{C}$ series occurred during a period of up to 205 years $(95 \%$ probability; Figure 5; calculated Difference between start: bone 1 and end: teeth), and probably less than 95 years (68\% probability). Nevertheless, this period of coexistence could be even shorter if we consider that we can guarantee that separately bone and teeth samples belong to different individuals but not when they are considered as a whole, which means that in some cases the same individual could have been dated twice. Consequently, it is possible that the most recent teeth dates belong to the older individuals dated on the basis of bone. If this was the case, the coexistence period will be significantly reduced.

3. The period of use is another important difference between teeth and bone ${ }^{14} \mathrm{C}$ series. In the first case, the ${ }^{14} \mathrm{C}$ dates on teeth show a large timespan for deposition $(620-1010$ years; 95\% probability; Figure 5; calculated Difference between start: teeth and end: teeth). The bone ${ }^{14} \mathrm{C}$ series sharply contrasts with this scenario as the two phases of mortuary activity identified display very short periods of use. The earliest phase spans 1-120 years (95\% probability; Figure 5; calculated Difference between start: bone 1 and end: bone 1), and probably no more than 40 years ( $68 \%$ probability), which means that no more than two generations would have been buried during this period. In the second phase, the dates clearly pass the test of contemporaneity $\left(T^{\prime}=0.3 ; T^{\prime}(5 \%)=3.8\right)$ (Ward and Wilson 1978), although the limited number of measurements available prevents drawing any robust conclusion.

It seems clear that the ${ }^{14} \mathrm{C}$ series of teeth samples dramatically change our chronological understanding of Tomb 10. The mortuary activity likely began in the fourth millennium although most of the interments were concentrated in middle half of the third millennium when the tomb reached its greatest ritual intensity. This period of use ended in 2465-2425 cal BC (68\% probability; Figure 4; end: Panoría main). Several centuries after this, the tomb was reused during a short period at the end of the third millennium. In contrast with what we noted in a previous paper (Aranda Jiménez et al. 2018a), the temporality of the tomb was not reduced to a short period of funerary activity, just the opposite, its use-life spanned centuries and contained complex sequences of mortuary depositions.

Not only funerary depositions, but the removal of bone remains emerges as a key aspect in the bone assemblage formation. The ${ }^{14} \mathrm{C}$ series based on teeth not only pushes back the beginning of mortuary activity by centuries but also suggests that teeth provide the evidentiary link to skeletal depositions subsequently removed from the tomb. Several reasons support this statement. The large ${ }^{14} \mathrm{C}$ series based on articulated and disarticulated bone remains robustly captures the temporality of the multi-depositional mortuary events. On the other hand, the series based on teeth shows a previous long period of funerary activity not identified by the ${ }^{14} \mathrm{C}$-dated bone samples. It is very remarkable that most of the teeth belong to funerary activities older than those identified by the bone samples. These chronological differences between teeth and bones are also very consistent with the osteological profile of the tomb characterized by a comparable representation between small and fragile bones and long bones. This signature in the representation of anatomical parts would also support the selective removal of skeletal remains for another use elsewhere.

\section{CONCLUSIONS}

The formation of bone assemblages is a key aspect for better understanding the ritual and funerary practices of megalithic societies. The palimpsest nature of the megalithic tombs characterized by multi-depositional events produce complex assemblages that appear to 
archaeological observation as fragmented, mixed and piled up on top of each other. Natural forces and social actions interact in complex ways to create these palimpsests. How these different factors leave distinct and recognizable signatures should be a main concern if we really want to base our interpretation on robust foundations. We have explored a novel methodology to investigate bone assemblage formation based on the ${ }^{14} \mathrm{C}$ chronology.

The ${ }^{14} \mathrm{C}$ dating of bone and teeth has shown that the removal of bone remains, as the anatomical part representation also suggests, was a major aspect of the ritual actions performed in Tomb 10. The dates of teeth show a long period of funerary use before the deposition of the human bone remains. It seems very plausible that these teeth were the evidence of skeletal remains that were removed in one or several episodes from the tomb to be taken to other places. The small size of the teeth and the fact that they easily detach from mandibles and maxillae would have favored their persistence in the tomb. Additionally, teeth are among the skeletal remains with the best rate of preservation, which make them an excellent indicator for exploring the full timespan of mortuary practices.

The ${ }^{14} \mathrm{C}$ series based on teeth show a long period of funerary activity whose end matches with the human bone deposition. Both kinds of samples seem to be chronologically sequenced with a short period of coexistence, probably less than 95 years $(68 \%$ probability). It seems that the human bone remains found in the tomb were the last episode of intense mortuary depositions. This episode spans a short period, not more than a few decades. Therefore, what appeared to the archaeological observer during the excavation process were mainly the last funerary depositions and not the remains of the entire use-life of the tomb. This also has important implications for the chronological discussion of the megalithic phenomenon. Without a careful analysis of the bone assemblage formation, traditional assumptions such as the association of the earliest dates with the construction of the megalithic tomb should be ruled out.

The opportunity to explore the bone assemblage formation of an undisturbed burial monument at the Panoría cemetery has offered an excellent opportunity to show how the complex interactions between the deposition and removal of human bone remains may blur the complexity of ritual actions and produce misleading interpretations. The ${ }^{14} \mathrm{C}$ chronology emerges as a useful pathway to explore assemblage formation through the temporality of the depositional events. Although this is a promising venue for untangling bone assemblage formation, further developments are needed if we really wish to understand megalithic monuments, one of the most widespread and long-lasting cultural manifestations of past societies.

\section{ACKNOWLEDGMENTS}

This work was supported by the Spanish Ministry of Economy and Competitiveness. Research project "Innovation, hybridisation and cultural resistance. The third and second millennia cal BC societies on the southern Iberian Peninsula" (HAR2017-82932-P). We would like to thank the editors and the anonymous reviewers whose suggestions helped to improve this paper.

\section{SUPPLEMENTARY MATERIAL}

To view supplementary material for this article, please visit https://doi.org/10.1017/RDC. 2020.67 


\section{REFERENCES}

Aranda Jiménez G, Lozano Medina A. 2014. The chronology of megalithic funerary practices: a Bayesian approach to Grave 11 at El Barranquete necropolis (Almería, Spain). Journal of Archaeological Science 50:369-382. doi: 10.1016/j.jas.2014.08.005.

Aranda Jiménez G, Lozano Medina A, Camalich Massieu MD, Martín Socas D., Rodríguez Santos FJ, Trujillo Mederos A, Santana Cabrera J., Nonza-Micaellie A, Clop García X. 2017. La cronología radiocarbónica de las primeras manifestaciones megalíticas en el sureste de la Península Ibérica: las necrópolis de Las Churuletas, La Atalaya y Llano del Jautón (Purchena, Almería). Trabajos de Prehistoria 74(2):257-277. doi: 10.3989/tp.2017.12194.

Aranda Jiménez G, Lozano Medina A, Sánchez Romero M, Díaz-Zorita Bonilla M, Bocherens H. 2018a. The chronology of the megalithic funerary practices in Southeastern Iberia: the necropolis of Panoría (Granada, Spain). Radiocarbon 60(1):1-19. doi: 10.1017/RDC.2017.96

Aranda Jiménez, G, Lozano Rodríguez JA, Pérez Valera F. 2018b. The megalithicnecropolis of Panoria, Granada, Spain. Geoarchaeological characterization and provenance studies. Geoarchaeology 33(2):260-270. doi: 10.1002/ gea.21643.

Aranda Jiménez G, Lozano Medina A, Díaz-Zorita Bonilla M, Sánchez Romero M, Escudero Carrillo J. 2018c. Cultural continuity and social resistance: The chronology of Megalithic funerary practices in southern Iberia. European Journal of Archaeology 21(2):192-216. doi: 10. 1017/eaa.2017.42.

Aranda Jiménez G, Díaz-Zorita Bonilla M, Hamilton D, Milesi L, Sánchez Romero M. 2020. The radiocarbon chronology and temporality of the megalithic cemetery of Los Millares (Almería, Spain). Archaeological and Anthropological Sciences 12. doi: 10.1007/ s12520-020-01057-7.

Bailey G. 2007. Time perspectives, palimpsests and the archaeology of time. Journal of Anthropological Archaeology 26:198-223.

Benavides López JA, Aranda Jiménez G, Sánchez Romero M, Alarcón García E, Fernández Martín S, Lozano Medina A, Esquivel Guerrero JA. 2016. 3D modelling in archaeology: The application of Structure from Motion methods to the study of the megalithic necropolis of Panoría (Granada, Spain). Journal of Archaeological Science: Reports 10:495-506. doi: 10.1016/j.jasrep.2016.11.022.

Bocherens H, Drucker D. 2003. Trophic level isotopic enrichments for carbon and nitrogen in collagen: case studies from recent and ancient terrestrial ecosystems. International Journal of Osteoarchaeology 13:46-53.
Bronk Ramsey C. 1995. Radiocarbon calibration and analysis of stratigraphy: the OxCal program. Radiocarbon 37(2):425-430.

Bronk Ramsey C. 2001. Development of the radiocarbon calibration program. Radiocarbon, 43(2):355-363.

Bronk Ramsey C. 2009a. Bayesian Analysis of radiocarbon dates. Radiocarbon 51(1):337-560.

Bronk Ramsey C. 2009b. Dealing with outliers and offsets in radiocarbon dating. Radiocarbon 51(3):1023-1045.

Buikstra JE, Ubelaker DH. 1994. Standards for data collection from human skeletal remains: Proceedings of a Seminar at the Field Museum of Natural History. Fayetteville: Archeological Survey, Research Seminar Series 44.

Chambon P. 2003. Les morts dans les sépultures collectives néolithiques en France. Du cadavre aux restes ultimes, Paris, CNRS.

Cook GT, Bonsall C, Hedges REM, Mcsweeney K, Boroneanţ V, Pettitt PT. 2001. A freshwater diet-derived ${ }^{14} \mathrm{C}$ reservoir effect at the Stone Age sites in the Iron Gates Gorge. Radiocarbon 43:453-460.

DeNiro MJ, Epstein S. 1978. Influence of diet on the distribution of carbon isotopes in animals. Geochimica et Cosmochimica Acta 49:97-115.

Díaz-Zorita Bonilla M. 2017. The Copper Age in SouthWest Spain. A boiarcheological approach to prehistoric social organization. Oxford: BAR Publishing.

Díaz-Zorita Bonilla M, Aranda Jiménez G, Robles Carrasco S, Escudero Carrillo J, Sánchez Romero M, Lozano Medina A. 2017. Estudio bioarqueológico de la necrópolis megalítica de Panoría (Darro, Granada). Menga. Revista de Prehistoria de Andalucía 8:91-114.

Díaz-Zorita Bonilla M, Aranda Jiménez G, Bocherens H, Escudero Carrillo J, Sánchez Romero M, Lozano Medina A, Alarcón García E, Milesi García L. 2019. Multi-isotopic diet analysis of southeastern Iberian megalithic populations: the cemeteries of El Barranquete and Panoría. Archaeological and Anthropological Science. doi: 10.1007/s12520-018-0769-5.

Dunbar E, Cook GT, Naysmith P, Tripney BG, Xu S. 2016. AMS ${ }^{14} \mathrm{C}$ dating at the Scottish Universities Environmental Research Centre (SUERC) Radiocarbon Dating Laboratory. Radiocarbon 58(1):9-23.

Hillson S. 1996. Dental anthropology. Cambridge: Cambridge University Press.

Knüsel C, Robb J. 2016. Funerary taphonomy: An overview of goals and methods. Journal of Archaeological Science: Reports. doi: 10.1016/j. jasrep.2016.05.031.

Lanting JN, van der Plicht J. 1998. Reservoir effects and apparent ${ }^{14} \mathrm{C}$ ages. Journal of Irish Archaeology 9:151-165. 
Leisner G, Leisner V. 1943. Die Megalithgräber der Iberischen Halbinsel: Der Süden. Berlin: Walter de Gruyter.

Lorrio Alvarado AJ. 2008. Qurénima. El Bronce Final del Sureste de la Península Ibérica. Madrid: Real Academia de la Historia. Universidad de Alicante.

Lorrio Alvarado AJ. 2011. Las sepultruas almerienses del Bronce Final excavadas por Luis Siret. In Cano García, J.A. editor. Almería, un museo a cielo abierto. La importancia de nuestra provincia en la historia de la Arqueología. Almería; Instituto de Estudios Almerienses. p. 37-76.

Lozano Medina A, Aranda Jiménez G. 2018. Longlasting sacred landscapes: The numerical chronology of the megalithic phenomenon in southeastern Iberia. Journal of Archaeological Science: Reports 19:224-238. doi: 10.1016/j. jasrep.2018.02.038.

Lucas G. 2005. The archaeology of time. London and New York: Routledge.

Maicas Ramos R. 2005. Rituales de enterramiento en la cuenca del Vera. In: Arias Cabal P, Ontañón Peredo R, García-Moncó Piñeiro C, editors. Actas del III Congreso del Neolítico en la Península Ibérica: Santander, del 5 a 8 de octubre de 2003. Santander. Universidad de Cantabria. p. 767-776.

Maicas Ramos R. 2007. Industria ósea y funcionalidad: Neolítico y Calcolítico en la Cuenca de Vera (Almería). Madrid: Consejo Superior de Investigaciones Científicas.

Millard A. 2014. Conventions for reporting radiocarbon determinations. Radiocarbon 56(2): 555-559.

Muñoz O, Ghazal RO, Guy H. 2012. Use of ossuary pits during the Umm an Nar period: New insights on the complexity of burial practices from the site of Ra's al-Jinz (RJ-1). In: Gernez G, GiraudGernez J, editors. Aux marges de l'archéologie. Hommage à Serge Cleuziou. Paris: Travaux de la maison René-Ginouvès, De Boccard. p. $451-467$.

Peña Romo V. 2011. Excavando huesos en los museos. El caso de la necrópolis de "Los Millares". In: González Martín A, Cambra-Moo O, Rascón Pérez J, Campo Martín M, Robledo Acinas M, Labajo González E, Sáchez Sánchez JA, editors. Paleopatología: ciencia multidisciplinar. Congreso Nacional de Paleopatología (Madrid, 10 de octubre de 2009). Madrid: Sociedad Española de Paleopatología. p. 73-80.
Reimer PJ, Bard E, Bayliss A, Beck JW, Blackwell PG, Bronk Ramsey C, Grootes PM, Guilderson TP, Haflidason H, Hajdas I, et al. 2013. IntCal13 and Marine13 radiocarbon age calibration curves $0-50,000$ years cal BP. Radiocarbon 55(4):1869-1887.

Robb J. 2016. What can we really say about skeletal part representation, MNI and funerary ritual? A simulation approach. Journal of Archaeological Science: Reports. doi: 10.1016/j.jasrep.2016.05.033.

Scarre C. 2007. The Megalithic monuments of Britain and Ireland. London and New York: Thames \& Hudson.

Schoeninger MJ, DeNiro MJ. 1984. Nitrogen and carbon isotopic composition of bone collagen from marine and terrestrial animals. Geochimica et Cosmochimica Acta 48:625-639.

Schulting RJ, Sebire H, Robb JE. 2010. On the road to Paradis: new insights from AMS dates and stable isotopes at Le Dehus, Guernsey, and the Channel Islandsmiddle Neolithic. Oxford Journal of Archaeology 29:149-173.

Siret L. 1891 [2001]. L'Espagne préhistorique. Almería: Consejería de Cultura de la Junta de Andalucía y Arráez Editores.

Siret L. 1893. L'Espagne préhistorique. Revue des Questions Scientifiques XXXIV:537-560.

Siret L. 1906-07. Orientaux et Occidentaux en Espagne aux temps préhistoriques. Revue des Questions Scientifiques X-XI:529-582.

Stuiver M, Braziunas TF. 1993. Modeling atmospheric ${ }^{14} \mathrm{C}$ influences and ${ }^{14} \mathrm{C}$ ages of marine samples to 10,000 BC. Radiocarbon 35(1):137-189.

Stuiver M, Polach HA. 1977. Reporting of ${ }^{14} \mathrm{C}$ data. Radiocarbon 19(3):355-363.

Stuiver M, Reimer PJ. 1993. Extended ${ }^{14} \mathrm{C}$ data base and revised CALIB $3.0{ }^{14} \mathrm{C}$ age calibration program. Radiocarbon 35(1):215-330.

Ward GK, Wilson SR. 1978. Procedures for comparing and combining radiocarbon age determinations: a critique. Archaeometry 20: 19-31.

Waterman AJ, Beck J, Thomas JT, Tykot RH. 2017. Stable isotope analysis of human remains from Los Millares cemetery (Almería, Spain, c. 32002200 cal BC): regional comparisons and dietary variability. Menga: Revista de Prehistoria de Andalucía 8:15-27.

Whittle A, Healy F, Bayliss A. 2011. Gathering time: dating the early Neolithic enclosures of southern Britain and Ireland, Oxford: Oxbow Books. 